\title{
ANALYSIS OF ANOMALIES OF QUAIL EMBRYONIC DEVELOPMENT IN EGG DURING INCUBATION IN THE CONDITIONS OF SPACE FLIGHT
}

\author{
O. A. DADASHEVA, Ye. Ya. SHEPELEV \\ Institute for Biomedical Problems, Moscow, Russia
}

Received June, 5, 1995

Accepted June 6, 1996

\begin{abstract}
Dada sheva O. A., Ye. Ya. Shepelev: Analysis of Anomalies of Quail Embryonic Development during Incubation in the Conditions of Space Flight. Acta vet. Brno 1996, 65: 39-41.

Three cycles of quail egg incubation were performed in the conditions of spaceflight in incubators of Slovak provenience. In these experiments, 22 embryos were obtained at different stages of development with a variety of anomalies. Frequency of these anomalies exceeded considerably that of terrestrial controls. Analysis of this unique material revealed that the majority of them were defects of the primary nerve structures of the brain and eye as a derivative brain rudiment. Such anomalies accounted for $65 \%$, while the remaining $35 \%$ were anomalies of ectoderm and mesoderm derivatives.

It is assumed that the main reasons for this high frequency of anomalies of avian embryogenesis under conditions of space flight are both vibrations and overloads during transfer of the spaceship to orbit. These factors cause changes in the position of the embryo within the egg related to its components such as the air chamber, yolk and albumen. Mechanic displacements of the embryo during launch are then further reinforced by the effects of weightlessness.
\end{abstract}

Embryogenesis, Japanese quail, microphthalmy, anophthalmy, deformations, ectopies

Analysis of three joint Russian and Slovak experiments on incubation of Japanese quail eggs is presented. The experiments were carried out in 1979, 1990 and 1992. The embryonic material obtained in these studies allows for first generalizations to be made. To our knowledge, almost no comparable data have been presented yet except for those of Hullinger (1993).

\section{Materials and Methods}

The material analyzed were 22 embryos that died at various stages of incubation during space flights as mentioned above. The ages of dead embryos were determined after landing using standard morphological criteria. Binocular magnifiers were used to aid the age determination. Morphological anomalies were studied in the laboratory.

\section{Results and Discussion}

The data collected from three space flights are summarized in Table 1. On the basis of these findings it is possible to make some preliminary conclusions.

1. The conditions for manifestations of the development anomalies took place in all spaceflights to equal and presumably they are an inevitable consequence of such flights, as far as the bird embryogenesis is concerned.

2. The particular forms of the embryo anomalies found during the experiments, are similar to those observed in terrestrial conditions, which means that there is no qualitative peculiarity of the effects of weightlessness; they influence only quantitative aspect, i.e. the increased frequency of the embryo development anomalies.

The embryogenesis processes are considerably dependent on the initial position of microcomponents of the egg structure: the yolk, the albumen, the air sac, and the embryo itself. This juxtaposition is normally determined only by gravity and in weightlessness it can be either retained or impaired. 
3. Maximum of the discovered embryogenesis anomalies were found in its early stages and were connected with primary nerve structures - defects of the development of brain and eye as a derivative brain rudiment. This corresponds to the first critical period of development of the quail embryo development on the 2nd-4 day which is mentioned in literature. Such anomalies made up $65 \%$ of all embryo anomalies in our material (Table 1).

Table 1

Types and numbers of anomalies of Japanese quail embryo development during incubation in the conditions of spaceflight

\begin{tabular}{|lcccc|}
\hline Type of anomaly & 1979 & 1990 & 1992 & total \\
\hline Unilateral microphtalmy & 3 & 4 & 2 & 9 \\
Bilateral microphtalmy & - & 1 & - & 1 \\
Unilateral anophtalmy & 1 & 2 & 2 & 5 \\
Bilateral anophtalmy & - & - & 1 & 1 \\
Cyclopy & 1 & - & - & 1 \\
Microcephaly & 4 & - & - & 4 \\
Anencephaly & - & 1 & - & 1 \\
Total & 9 & 2 & 5 & 22 \\
\hline Beak deformations & - & - & 2 & 6 \\
Internal organs ectopy & 1 & - & 1 & 3 \\
Underdevelopment of & 2 & 2 & 7 & 3 \\
lower limbs & 3 & 10 & 12 & 12 \\
Total & 12 & & 34 \\
\hline Sum of all anomalies & & & & 3 \\
\hline
\end{tabular}

4. The remaining $35 \%$ of anomalies of development took place during the later differentiation periods in ectoderm, endoderm and mesoderm where there were probably their own critical periods.

The particular quantity of possible development anomalies is presumably very limited. It may be determined by the genetic program of embryogenesis and morphogenetic potentials of the embryonic material at different stages of development.

5. It is important to emphasize that the mentioned anomalies of embryogenesis were practically absent in the ground-based synchronous control where all vibrations and overloads were reproduced inherent to the period of transfer the spaceship to orbit. It may be explained by the further regulation of the anomalies of the egg macrostructure which have appeared at that period in the terrestrial conditions. But it also means that after overloads of an actual flight, continued weightlessness enhances the structural changes of the egg which have appeared earlier, and lays the foundation of what we call the influence of weightlessness on embryogenesis.

\section{Analýza anomálií embryonálneho vývoja prepelice $v$ násadových vajíčkach v podmienkach vesmírneho letu}

Počas troch kozmických letov bolo získaných 22 embryí na rôznych úrovniach embryonálneho vývoja $\mathrm{s}$ rozdielnymi anomáliami. Zovšeobecnenie získaného materiálu s ohladom na anomálie embryonálneho vývoja, frekvencia ktorých značne prekročila ich výskyt $v$ podmienkach vývoja na Zemi, ukázalo, že väčšina anomálií súvisela s defektami primárnych nervových štruktúr mozgu a oka. Ich pôvod vychádza z mozgového rudimentu. Tieto anomálie dosahovali $65 \%$. 
Ďalších $35 \%$ vývojových anomálií sa týkalo štruktúr ektodermálneho a mezodermálneho pôvodu. Bola vyslovená domnienka, že hlavnou príčinou vysokého výskytu anomálií embryonálneho vývoja vtákov v podmienkach vesmírneho letu sú vibrácie a pretaženie počas cesty vesmírnej lode na obežnú dráhu. Tieto vyvolávajú zmenu polohy embrya vo vztahu k dôležitým komponentom vajíčka ako je vzduchová komôrka, žltok a bielok. Stav beztiaže, ktorý potom nasleduje, fixuje mechanické presuny v makroštruktúre vajícka.

\section{Анализ аномалий эмбрионального развития перепела при инкубировании яиц в условиях космического полета}

Были осуществлены три цикла инкубирования яиц перепела в условиях космического полета в инкубаторах, разработанных совместно со специалистами Словацкой академии наук.

За это время было получено 22 эмбриона на разных стадиях эмбрионального развития с различными нарушениями. Обобщение полученного материала по нарушениям развития эмбрионов, частота которых существенно превышала их частоту в наземных контролях, показало, что большая часть нарушений эмбриогенеза была связана с дефектами развития первичных нервных структур головного мозга и глаза, как производного мозгового зачатка. Их было $65 \%$. Остальные 35 \% нарушений развития приходились на производные эктодермы и мезодермы.

Высказывается предположение, что основной птичиной повышенной частоты нарушений эмбриогенеза птиц в условиях космического полета являются вибрация и перегрузки в период выведения космического корабля на орбиту. Они являются причиной изменения положения зародыша по отношению к важным для него компонентам яйца - воздушной камере, желтку и белку. Наступающая после этого невесомость только закрепляет, фиксирует возникшие механические перемещения в макроструктуре яйца.

\section{References}

BOĎA, K., SABO, V., JURÁNI, M., GURYEVA, T. S., KOČIŠOVÁ, J., KOŠTÁL, L., LAUKOVÁ, A., DADASHEVA, O. A.: 1992, Acta vet. Brno, 61:99-107

HULLINGER, R. L. 1993: Acta vet. Brno, Suppl. 6, 62:S17-S23

MELESHKO, G. I., SHEPELEV, Ye. Ya., GURYEVA, T. S., BOĎA, K., SABO, V.: 1991 Kosmitcheskaya biologiya i aviakosmitcheskaya medicina, Moskva, 1:37-39

SHEPELEV, Ye. Ya., BODA, K., MISHENKO, V. F., FOFANOV, V. I., DADASHEVA, O. A., BELAK, M., SIDORENKO, L. A., PETER, V., SABO, V., KOČIŠOVÁ, J., MARETTA, M. 1982: XI. Soveshaniye rabotchej gruppy po kosmitcheskoy biologi: i medicine. Interkosmos, Tezisy dokladov, Bukharest, pp. 121-122

SHEPELEV, Ye. Ya., GURYEVA, T. S., SOLOVYOV, A. Ya., BODA, K., SABO, V. 1993: Acta vet. Brno, suppl. 6, 62:S61-S63 